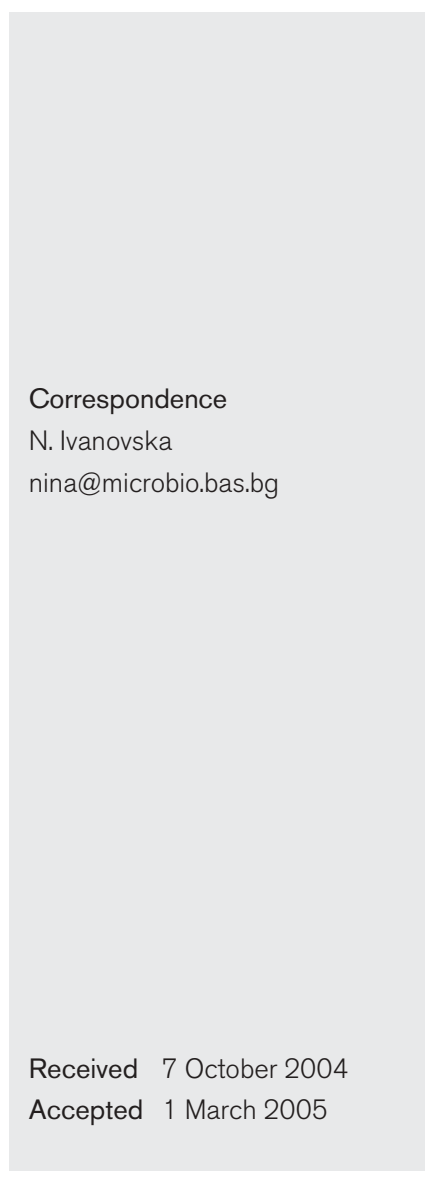

\section{lbogaine reduces organ colonization in murine systemic and gastrointestinal Candida albicans infections}

\author{
M. Yordanov, ${ }^{1}$ P. Dimitrova, ${ }^{1}$ S. Patkar, ${ }^{2}$ S. Falcocchio, ${ }^{3}$ E. Xoxi, ${ }^{3}$ L. Saso ${ }^{3}$ \\ and N. Ivanovska ${ }^{1}$ \\ ${ }^{1}$ Department of Immunology, Institute of Microbiology, 26 G. Bonchev Str., 1113 Sofia, Bulgaria \\ ${ }^{2}$ Novozymes A/S, Novo Allé, DK-2880, Bagsvaerd, Denmark \\ ${ }^{3}$ Department of Human Physiology and Pharmacology 'Vittorio Erspame', University of Rome 'La \\ Sapienza', P. le Aldo Moro 5, 00185 Rome, Italy
}

\section{INTRODUCTION}

Candida albicans is an opportunistic fungal pathogen with a rising incidence of severe disseminated infections leading to fatal outcomes in humans (Fidel et al., 1999; Komshian et al., 1989; Pfaller, 1996). A number of factors have contributed to this, for example the wide use of immunosuppressive therapies and the increased cases of immune-deficiency diseases, such as AIDS (Shearer, 1998). The limited number of effective antifungals against C. albicans is further reduced by the appearance of drug-resistant species. The discovery of new compounds with different mechanisms of action is a challenge in antifungal drug research.

While immunity to Candida has been thoroughly investigated, the factors connected with the early penetration of the yeast into the host cells are less defined and exploited. Microorganisms can damage host cell membranes through secretion of different proteolytic and lipolytic enzymes. It has been proven that $C$. albicans produces extracellular lipases, and since the characterization of the gene LIP1 (Fu et al., 1997) nine new members of a family encoding lipases have been identified (Hube et al., 2000). An important observation is

Abbreviations: AmB, amphotericin B; DTH, delayed-type hypersensitivity reaction; IFN, interferon; i.v., intravenously. that some of these LIP genes are expressed in infected organs during systemic C. albicans infection. These data suggest that lipases might be involved in the pathogenesis of the yeast.

Phospholipases belong to a heterogeneous group of enzymes capable of destroying cell membranes. Many investigations support the view that they act as pathogenic factors in protozoan (Saffer \& Schwartzman, 1991), bacterial (Portnoy et al., 1994; Songer, 1997; Titball, 1993) and fungal (Cox et al., 2001; Leidich et al., 1998) infections. Genes encoding phospholipase B and C have recently been cloned (Bennett et al., 1998; Sugiyama et al., 1999). According to a classification of phospholipases, based on the type of ester link that is cleaved, a single enzyme can express phospholipase B activity and also lysophospholipase and transacyclase activity. If it is the case that all these activities are controlled by one gene product, it is difficult to correlate a certain biological effect with a single enzyme. In vivo data demonstrate that phospholipase-deficient $C$. albicans mutants are less invasive (Ghannoum, 2000; Mukherjee et al., 2001). Targeted gene disruption is one of the most promising approaches to evaluate the contribution of different extracellular products to the virulence of $C$. albicans. Using this method, Leidich et al. (1998) showed that the disruption of a gene encoding a phospholipase B had no effect on yeast growth but significantly reduced its penetration into host cells and its virulence 
in a murine model of disseminated candidiasis. Also, a $C$. albicans strain lacking a gene encoding a phosphatidylcholine-specific phospholipase $\mathrm{D}$ is less virulent in a model of oral infection (Hube et al., 2001).

Targeting lipolytic enzymes might represent a novel approach in antimicrobial therapy, including therapy for $C$. albicans infections (Andriole, 1999). The application of lipase and phospholipase inhibitors can influence the early phase of $C$. albicans penetration and colonization of host tissues. Some beta-blocker-like structures have inhibitory activity on phospholipases and correlate with a protective effect during C. albicans infections (Hanel et al., 1995).

In a preliminary screen of a series of compounds, we observed an inhibitory effect of the indole alkaloid ibogaine on the activity of several lipases. In this context, some indoline alkaloids, analogues of $\beta$-carbolines, have been shown to possess antifungal activity in vitro equal to that of amphotericin B (AmB) but with low cytotoxicity (Kariba et al., 2002). The antifungal or antilipase activity of ibogaine has not been investigated. Thus, in the present study we decided to study the influence of ibogaine on C. albicans lipase activity, cell adherence and on disseminated and gastrointestinal C. albicans infections in relation to organ colonization and specific immune responses.

\section{METHODS}

Reagents. Candida rugosa lipase (Crl) was purchased from Nippon Fats and Oil and further purified by ion exchange chromatography. Thermomyces lanuginosa lipase (TLL), Fusarium oxysporum lipase (Fol), Candida antarctica lipase A (CALA), C. antarctica lipase B (CALB) and Rhizomucor miehei lipase (Rml) were expressed in Aspergillus oryzae and purified at Novozymes. All lipases used for this study were more than $95 \%$ pure as determined by SDS-PAGE. Ibogaine and AmB were obtained from Sigma.

Evaluation of lipase activity. $p$-Nitrophenyl-butyrate was used as a substrate and the release of $p$-nitrophenol was measured spectrophotometrically at $405 \mathrm{~nm}$ using a microplate reader. As each lipase has different activity on $p$-nitrophenyl-butyrate as a substrate, a pilot experiment was carried out to find the optimal amount of each enzyme to give linear kinetics for $p$-nitrophenol formation and to give an $\mathrm{OD}_{405}$ of 1 after a 5 min incubation. Aliquots of $100 \mu$ of each enzyme, diluted in $50 \mathrm{mM}$ borate ( $\mathrm{pH} 8$ ), were pipetted into a 96-well microplate and the reaction was started by adding $100 \mu \mathrm{l}$ of the substrate. $p$-Nitrophenylbutyrate was prepared as $100 \mathrm{mM}$ stock solution in 2-propanol and diluted 1:100 in $50 \mathrm{mM}$ borate $(\mathrm{pH} 8)$ just before use. The final concentration in the microtitre well was $0.5 \mathrm{mM}$ of the substrate.

Assay of lipase inhibition. Ibogaine dissolved in DMSO at a concentration of $1 \mathrm{mg} \mathrm{ml}^{-1}$ was pipetted into the microtitre wells and $100 \mu \mathrm{l}$ of the optimal amount of each lipase was added. After incubation for $5 \mathrm{~min} 100 \mu \mathrm{l}$ of the substrate was added. The reaction was followed by measuring $p$-nitrophenol produced after $5 \mathrm{~min}$ as described above. During the assay, the plate was constantly agitated. Blanks, using the same amount of DMSO without ibogaine, were also assayed.

Determination of the reversibility of the inhibition. All the enzymes were dissolved in $1 \mathrm{ml} 50 \mathrm{mM}$ HEPES $\left(\mathrm{pH} 7.0\right.$ at $22^{\circ} \mathrm{C}$ ) to a concentration of $3.5 \times 10^{-6} \mathrm{M}$, and $10 \mu \mathrm{l}$ of ibogaine dissolved in DMSO to a concentration of $100 \mathrm{mM}$ was added and the samples were incubated for 30 min at room temperature. All the enzymes were then diluted at least 750 -fold in water and residual enzymic activity was assayed using the $\mathrm{pH}$-stat assay with tributyrine emulsified with gumarabic as a substrate.

In vitro candidacidal activity. The antifungal activity of ibogaine on $C$. albicans was tested by a diffusion method. Ibogaine at a concentration range from 0.05 to $1.0 \mathrm{mg} \mathrm{ml}^{-1}$ was pipetted into $20 \mathrm{~mm}$ wells in Sabouraud agar inoculated with $1 \times 10^{5}$ Candida cells ml ${ }^{-1}$. After $48 \mathrm{~h}$ at $37^{\circ} \mathrm{C}$ the zone of inhibition was measured. $\mathrm{AmB}$ was used as a positive control.

Extracellular phospholipase activity. Extracellular phospholipase activity was determined by the method of Price et al. (1982). Ten microlitres of C. albicans suspension $\left(1 \times 10^{5}\right.$ cells ml $\left.^{-1}\right)$ was plated on Sabouraud agar containing $5 \mathrm{mM} \mathrm{CaCl} 2$ and $8 \%$ Bacto Egg Yolk (Difco) for $48 \mathrm{~h}$ at $30{ }^{\circ} \mathrm{C}$. Phospholipase secretion produced a distinct opaque zone around the colonies.

Extracellular lipase activity. Yeast cells were washed with PBS and adjusted to $5 \times 10^{6}$ cells $\mathrm{ml}^{-1}$ in different growth media in the presence or absence of $250 \mu \mathrm{g}$ ibogaine $\mathrm{ml}^{-1}$. The flasks were shaken at $37^{\circ} \mathrm{C}$ for $24 \mathrm{~h}$. The lipolytic activity in filtrated culture supernatants was determined by a plate assay on olive oil agar that contained $0.7 \%$ yeast nitrogen base (YNB; Difco) (w/v), 2\% olive oil (v/v), 0.001\% rhodamine B (w/v) and $2 \%$ agar $(\mathrm{w} / \mathrm{v})$. The following liquid media were used for C. albicans growth: minimal (YNB without glucose and amino acids), yeast peptone glucose (YPG; Difco), 0.67\% (w/v) YNB containing $2 \cdot 5 \%(\mathrm{v} / \mathrm{v})$ Tween 20 , Tween 40 or Tween 80 (Sigma).

Adherence assay. Late-exponential-phase yeast cells were harvested, washed twice in $0.9 \% \mathrm{NaCl}$ and resuspended to $1 \times 10^{2} \mathrm{cells} \mathrm{ml}^{-1}$ in Hanks' balanced salt solution (HBSS). One millilitre of this suspension was added to an HT-29 epithelial cell line monolayer in six-well tissueculture plates. Following incubation for $15 \mathrm{~min}$ at $37^{\circ} \mathrm{C}$ in the absence (taken as $100 \%$ adherence) or presence of different ibogaine concentrations, the nonadherent yeast cells were aspirated and each well was rinsed twice with HBSS. Next, the wells were overlaid with Sabouraud agar and the number of adherent C. albicans was quantified by colony counting (repeated in triplicate). Dose-response curves were drawn by plotting the inhibition of adherence against dilutions of the substance. From this the concentration giving $50 \%$ inhibition of adherence was determined.

C. albicans systemic and gastrointestinal infections. Male and female BALB/c mice (Iffa-Credo, Charles River, L’Arbresle, France) were kept on a standard commercial pellet diet with water ad libitum. The animal use protocols were approved by the Animal Care Commission at the Institute of Microbiology according to international laws.

A virulent clinical isolate of C. albicans, 562 (Institute of Infectious and Parasitic Diseases, Sofia, Bulgaria), was used in the study. Prior to inoculation, the yeast was grown for $48 \mathrm{~h}$ on Sabouraud broth (Difco) at $37^{\circ} \mathrm{C}$. After methylene-blue staining no hyphae were observed. A standard curve was drawn by plotting the $\mathrm{OD}_{620}$ against the concentration of the yeast, determined by counting the c.f.u. of different suspensions.

For lethal disseminated infection, $1 \times 10^{6}$ cells in $0 \cdot 1 \mathrm{ml}$ sterile pyrogen-free PBS was injected into the tail vein of the mice.

To induce gastrointestinal infection, mice were given water containing $1 \mathrm{mg}$ amoxicillin $\mathrm{ml}^{-1}$ (Yamanouchi B.V. Netherlands) and $0.1 \mathrm{mg}$ amikacin $\mathrm{ml}^{-1}$ (Amikin, Bristol Lab., USA) for 7 days before inoculation. Mice were infected by an oral administration of $1 \times 10^{7}$ cells of $C$. albicans in a volume of $0 \cdot 1 \mathrm{ml}$ with a gastric gavage. Ibogaine and $\mathrm{AmB}$ were dissolved in sterile distilled water and injected intraperitoneally at a dose of $0.5 \mathrm{mg} \mathrm{kg}^{-1}$ in a volume of $0.2 \mathrm{ml}$. 
At different intervals, the mice were killed and various organs were removed aseptically, weighed and homogenized in a glass tissue grinder with $5 \mathrm{ml}$ of saline. Tenfold serial dilutions were made of each homogenate and plated on Sabouraud agar, and the colonies were counted after $24 \mathrm{~h}$.

Delayed type hypersensitivity (DTH) reaction. Mice were inoculated intravenously with $1 \times 10^{6} \mathrm{C}$. albicans cells. Five animals from each group were injected at day 20 of infection with $1 \times 10^{7}$ glutaraldehydeinactivated Candida cells (treated overnight at $4{ }^{\circ} \mathrm{C}$ with $2 \%$ glutaraldehyde) into the hind paw. After $24 \mathrm{~h}$ the footpad thickness of the injected paw was measured and the difference with the control paw, injected with saline, was calculated in millimetres. A control group of non-infected mice was injected in the same way with inactivated yeast cells.

Cytokine assay. At day 8 of intravenous (i.v.) infection, cell suspensions were prepared from freshly removed spleens and erythrocytes were depleted using lysis buffer $\left(0 \cdot 15 \mathrm{M} \mathrm{NH}_{4} \mathrm{Cl}, 10 \mathrm{mM} \mathrm{KHCO}, 0 \cdot 1 \mathrm{mM}\right.$

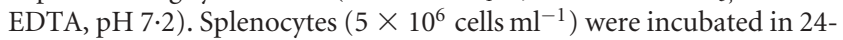
well Falcon plates (Becton Dickinson) in RPMI 1640 media (Gibco$\mathrm{BRL}$ ), containing $10 \%$ fetal bovine serum (Sigma), $100 \mathrm{U}$ penicillin $\mathrm{ml}^{-1}, 100 \mu \mathrm{g}$ streptomycin $\mathrm{ml}^{-1}$ (Sigma), $2 \mathrm{mM}$ L-glutamine, $25 \mathrm{mM}$ $\beta$-mercaptoethanol and $10 \mathrm{mM}$ HEPES. Cytokine concentrations were determined in the supernatants after 3 days of culture in the presence or absence of $1 \times 10^{7}$ glutaraldehyde-inactivated C. albicans cells. Quantitative ELISA for interferon (IFN) $-\gamma$ was performed using paired $\mathrm{mAbs}$ according to manufacturer's recommendations (Euroclone). The minimum detectable concentration was less than $15 \mathrm{pg} \mathrm{ml}^{-1}$.

Statistical analysis. The statistical difference in the survival rate or c.f.u. was examined by Wilcoxon test or by Student's $t$-test, respectively.

\section{RESULTS}

\section{In vitro ibogaine activity}

In the present study, the indole alkaloid agent ibogaine was used (Fig. 1). First, we evaluated the effect of ibogaine on several fungal lipolytic enzymes such as $F$. oxysporum lipase (Fol), C. rugosa lipase (Crl) and the R. miehei lipase (Rml). Ibogaine showed high levels of inhibition at a concentration range from $10^{-4} \mathrm{M}$ to $10^{-6} \mathrm{M}$ (Fig. 2). Its mechanism of action appeared to be reversible, since the enzyme activity was restored after ibogaine removal.

The plate diffusion assay showed that ibogaine had no candidacidal effect on C. albicans up to a concentration of $500 \mu \mathrm{g} \mathrm{ml}^{-1}$. We established that the strain produced extracellular lipase or phospholipases, sufficient for detection on egg yolk agar. The preincubation of C. albicans with $100-$ $1000 \mu \mathrm{g}$ ibogaine $\mathrm{ml}^{-1}$ for $24 \mathrm{~h}$ before seeding on yolk agar resulted in a less-marked opaque zone at concentrations above $500 \mu \mathrm{g} \mathrm{ml}^{-1}$ (not shown).

In the next experiments it was shown that the yeast expressed lipolytic activity when grown in YPG medium or in a medium containing Tween 40 as a sole carbon source (Fig. 3). Such activity was not detected in a minimal medium or in YNB with Tween 20 or Tween 80 . Yeast cells were grown for $24 \mathrm{~h}$ and at different intervals the supernatants were collected, the $\mathrm{pH}$ was measured and the cells were counted. The lipolytic activity increased slowly during the first $6 \mathrm{~h}$ of

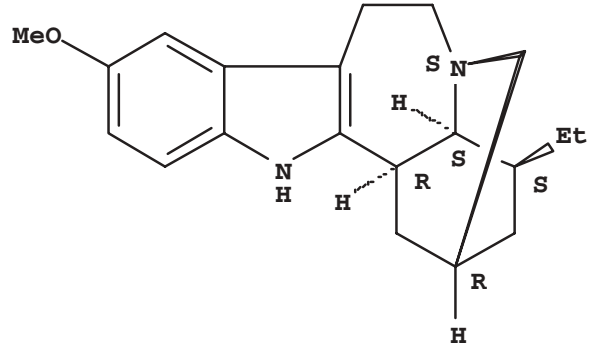

Fig. 1. Ibogaine.

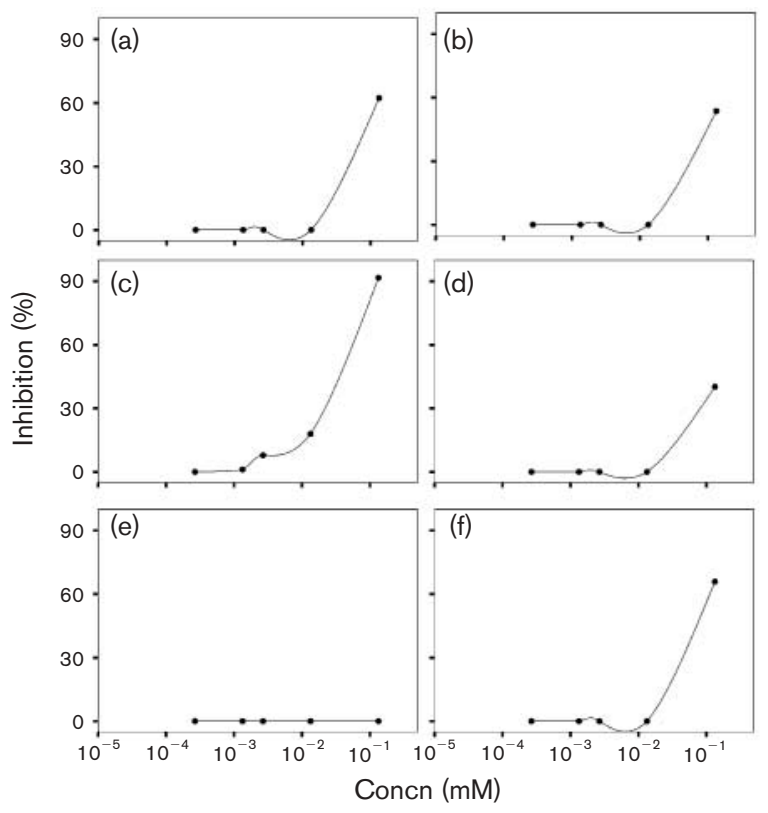

Fig. 2. Inhibition of selected lipases by ibogaine. Effect of ibogaine on the activity of (a) T. lanuginosa, (b) F. oxysporum, (c) C. rugosa, (d) C. antarctica $A,(e) C$. antarctica B and (f) R. miehei lipases.

growth as no substantial difference in cell number or $\mathrm{pH}$ was observed. Therefore, the data in Fig. 3 represent the effect of ibogaine after $6 \mathrm{~h}$ of cultivation. It is evident that the substance inhibited the lipolytic activity of the yeast in both YPG medium and in YNB with Tween 40.

When ibogaine was tested in adherence assays, the substance caused a $50 \%$ inhibition of $C$. albicans attachment to the HT-29 epithelial cell line at a concentration of $52 \cdot 0 \pm$ $0 \cdot 4 \mu \mathrm{g} \mathrm{ml}^{-1}$.

\section{In vivo ibogaine activity}

Ibogaine was administered intraperitoneally at a dose of $5 \mathrm{mg} \mathrm{kg}^{-1}$ for the first 3 days of i.v. C. albicans infection. The rate of mortality was significantly decreased in the ibogainetreated group (Fig. 4). The number of $C$. albicans c.f.u. recovered from the kidneys, liver and spleen was reduced as a 


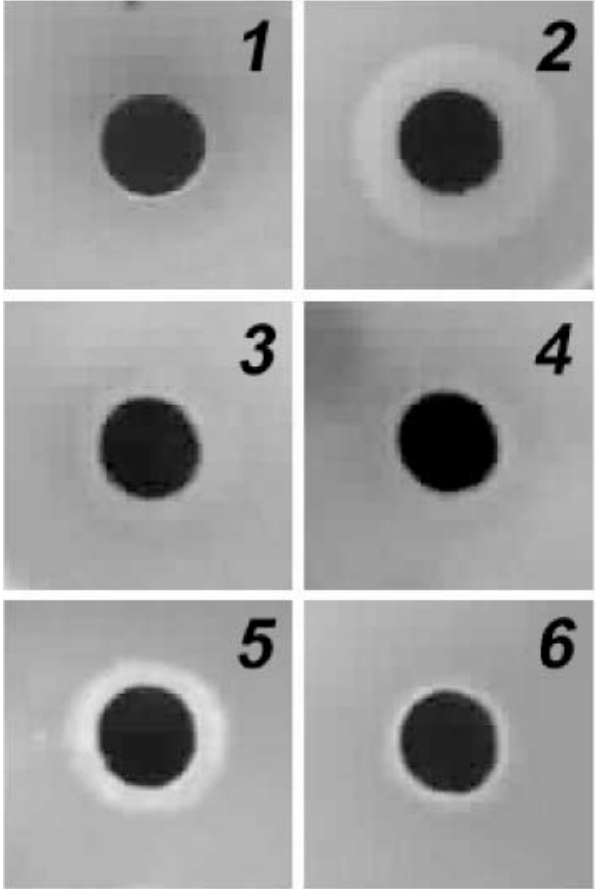

Fig. 3. Detection of lipolytic activity in the culture supernatants after $6 \mathrm{~h}$ growth of $C$. albicans in the presence or absence of $250 \mu \mathrm{g}$ ibogaine $\mathrm{ml}^{-1}$. Panels: YPG medium as a negative control (1); lipase of C. rugosa $\left(250 \mu \mathrm{g} \mathrm{ml}^{-1}\right)$ as a positive control (2); YPG medium inoculated with $C$. albicans in the absence (3) or presence (4) of ibogaine; YNB containing Tween 40 inoculated with the yeast in the absence (5) or in the presence (6) of ibogaine.

result of ibogaine administration at day 4 and 10 of infection (Table 1). At day 28 of infection ibogaine-treated and nontreated mice showed similar kidney colonization, while in both groups liver contamination was low and the spleen was free of the yeast. Ibogaine-treatment did not affect brain colonization.

At day 21 of infection the DTH reaction to C. albicans was determined. The data show that ibogaine-treated and non-

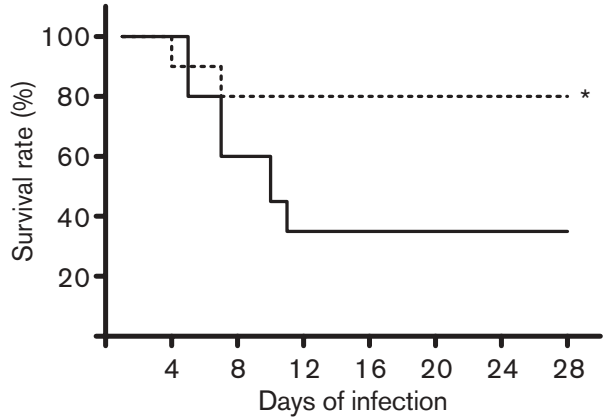

Fig. 4. Effect of ibogaine treatment on the survival of mice intravenously inoculated with $1 \times 10^{6}$ c.f.u. of C. albicans. Mice were injected intraperitoneally with $5 \mathrm{mg}$ ibogaine $\mathrm{kg}^{-1}$ from day 0 to day 3 of infection. Control mice, solid line; ibogaine-treated mice, dashed line. Each group consisted of 10 animals, and data are representative of three independent experiments. ${ }^{*} P<0.001$, Wilcoxon test.

treated animals developed significant swelling $24 \mathrm{~h}$ after injection of the inactivated yeast into the paw. The swelling measured was $4.7 \pm 0.3 \mathrm{~mm}$ in the control group and $5.6 \pm 0.2 \mathrm{~mm}$ for treated mice. Eight days after i.v. infection, spleen cells were isolated from ibogaine-treated and nontreated mice, and stimulated in vitro with inactivated $C$. albicans. After $48 \mathrm{~h}$ of growth the concentration of IFN- $\gamma$ in the supernatants was assayed. No difference was observed in the cytokine secretion by splenocytes from ibogaine-treated and nontreated groups $\left(300 \pm 20 \mathrm{pg} \mathrm{ml}^{-1}\right.$ and $280 \pm 25 \mathrm{pg}$ $\mathrm{ml}^{-1}$, respectively).

To induce gastrointestinal infection, mice were given two antibiotics orally to reduce the number of intestinal microflora and then were inoculated orally with $1 \times 10^{8} \mathrm{C}$. albicans cells. In preliminary experiments a comparison was made with mice not receiving antibiotics. It was established that $2.6 \times 10^{6}$ c.f.u. $\mathrm{g}^{-1}$ (day 5 of inoculation), $2 \cdot 2 \times 10^{6}$ c.f.u. $\mathrm{g}^{-1}$ (day 10) and $1.6 \times 10^{6}$ c.f.u. ${ }^{-1}$ (day 15) C. albicans were isolated from the faeces of animals fed with antibiotics. In the faeces of C. albicans-infected mice without antibiotic treatment the yeast was not detected after day $5\left(<2 \times 10^{2}\right.$

Table 1. Distribution of C. albicans in different organs after intravenous infection

Mice were inoculated intravenously with $5 \times 10^{6}$ c.f.u. of C. albicans and treated with ibogaine intraperitoneally at a dose of $5 \mathrm{mg} \mathrm{kg}^{-1}$ from day 0 to day 3 of infection. At the indicated days various organs (five mice per point) were removed, homogenized and plated for determination of c.f.u. per gram of tissue. Data were similar in three experiments and are represented as mean $\pm \mathrm{SD}$. ${ }^{\star} P<0 \cdot 05 ;{ }^{* *} P<0 \cdot 01$; ${ }^{* *} P<0 \cdot 001$.

\begin{tabular}{|c|c|c|c|c|c|c|c|c|}
\hline \multirow{2}{*}{$\begin{array}{l}\text { Days of } \\
\text { infection }\end{array}$} & \multicolumn{2}{|c|}{ Kidneys (log c.f.u. $g^{-1}$ ) } & \multicolumn{2}{|c|}{ Liver (log c.f.u. $\left.g^{-1}\right)$} & \multicolumn{2}{|c|}{ Spleen (log c.f.u. $\mathrm{g}^{-1}$ ) } & \multicolumn{2}{|c|}{ Brain (log c.f.u. $g^{-1}$ ) } \\
\hline & Control & $\begin{array}{l}\text { Ibogaine- } \\
\text { treated }\end{array}$ & Control & $\begin{array}{l}\text { Ibogaine- } \\
\text { treated }\end{array}$ & Control & $\begin{array}{l}\text { Ibogaine- } \\
\text { treated }\end{array}$ & Control & $\begin{array}{c}\text { Ibogaine- } \\
\text { treated }\end{array}$ \\
\hline 4 & $5 \cdot 2 \pm 0 \cdot 5$ & $3 \cdot 8 \pm 0 \cdot 4^{\star *}$ & $7 \cdot 0 \pm 1 \cdot 0$ & $4 \cdot 8 \pm 0 \cdot 5^{\star \star}$ & $5 \cdot 2 \pm 0 \cdot 8$ & $3 \cdot 4 \pm 0 \cdot 6^{\star *}$ & $<2 \cdot 0$ & $<2 \cdot 0$ \\
\hline 10 & $6 \cdot 4 \pm 0 \cdot 6$ & $5 \cdot 4 \pm 0 \cdot 8^{*}$ & $4 \cdot 4 \pm 0 \cdot 4$ & $3 \cdot 0 \pm 0 \cdot 5^{\star *}$ & $4 \cdot 0 \pm 0 \cdot 5$ & $<2 \cdot 0^{* * *}$ & $3 \cdot 0 \pm 0 \cdot 4$ & $2 \cdot 4 \pm 0 \cdot 2$ \\
\hline 28 & $4 \cdot 0 \pm 0 \cdot 6$ & $3 \cdot 8 \pm 0 \cdot 4$ & $2 \cdot 0 \pm 0 \cdot 5$ & $2 \cdot 2 \pm 0 \cdot 4$ & $<2 \cdot 0$ & $<2 \cdot 0$ & $2 \cdot 8 \pm 0 \cdot 5$ & $<2 \cdot 0^{\star}$ \\
\hline
\end{tabular}


c.f.u. $\mathrm{g}^{-1}$ ). Two days after the final ibogaine-treatment (at a dose of $5 \mathrm{mg} \mathrm{kg}^{-1}$ from day 0 to day 3 of infection), fewer c.f.u. of $C$. albicans were counted in the stomach of this group than in nontreated mice (Fig. 5). At day 20 ofinfection no difference was observed between ibogaine-treated and nontreated animals. At that time point the mice stopped receiving the antibiotics and in a similar manner the stomach colonization decreased in both groups until day 35 . This was probably due to the recovery of the commensal microflora, since mice maintained on antibiotics showed higher stomach colonization (data not shown).

In the next experiments ibogaine treatment was continued until day 5 of infection at a dose of $5 \mathrm{mg} \mathrm{kg}^{-1}$. Additionally, a group of mice was treated for 5 days with a suboptimal dose of $0.5 \mathrm{mg} \mathrm{AmB} \mathrm{kg}^{-1}$ and a group was injected with $0.5 \mathrm{mg} \mathrm{AmB} \mathrm{kg}^{-1}$ plus $5 \mathrm{mg}$ ibogaine $\mathrm{kg}^{-1}$. Two weeks later the colonization of stomach and kidneys was examined (Table 2). There was a significant reduction in the number of c.f.u. in both organs in mice injected with ibogaine or with $\mathrm{AmB}$ plus ibogaine. The combined treatment was more effective than the ibogaine administration alone, statistically significant in respect to kidney colonization.

\section{DISCUSSION}

In humans who develop systemic yeast infections it is supposed that the source of the micro-organism is the digestive tract, where C. albicans is a part of the normal flora (Wenzel, 1995). One possible approach to limit yeast penetration into the host cells is through the inhibition of fungal enzymes engaged in the destruction of cell surface membranes. Since our in vitro data showed that ibogaine is capable of inhibiting several lipases and also of preventing the adherence of $C$. albicans to epithelial cells, we theorized that this substance may have beneficial effects during in vivo infections.

C. albicans expressed lipolytic activity not only in a medium containing Tween 40 as a sole source of carbon but also in a

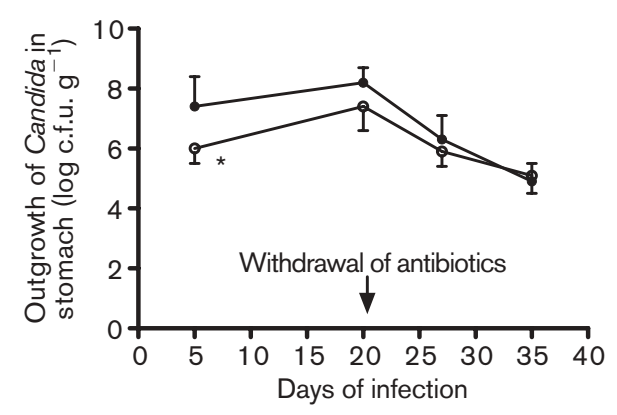

Fig. 5. Outgrowth of $C$. albicans in the stomach. For the induction and maintenance of gastrointestinal infection, mice were fed with antibiotics from day -7 to day 20 . At different time points after inoculation with $1 \times 10^{7}$ cells five animals from ibogaine-treated $(\bigcirc)$ and nontreated (-) groups were killed to assess the viable C. albicans cells. Data were similar for three experiments and represent means \pm SD. ${ }^{*} P<0 \cdot 05$, Student's t-test.
Table 2. Contamination of stomach and kidneys after intragastric inoculation

Ten days after last treatment (day 15 of infection) organs were removed and assessed for yeast growth. Values are mean \pm SD from five mice per group. Experiments were performed three times. ${ }^{\star} P<0.05$ vs control; ${ }^{\star \star} P<0 \cdot 05$ vs ibogaine-treated group; ${ }^{\star \star *} P<0 \cdot 001$.

\begin{tabular}{|llc|}
\hline Group & \multicolumn{2}{c|}{$\begin{array}{c}\text { Viable Candida cells } \\
{\left[\log \text { c.f.u. }\left(\text { g tissue }^{-1}\right)\right]}\end{array}$} \\
\cline { 2 - 3 } & Stomach & Kidney \\
\hline Control $\dagger$ & $6 \cdot 8 \pm 0 \cdot 5$ & $4 \cdot 3 \pm 0 \cdot 8$ \\
AmB $\ddagger$ & $6 \cdot 4 \pm 0 \cdot 8$ & $4 \cdot 9 \pm 0 \cdot 8$ \\
Ibogaine§ & $4 \cdot 6 \pm 0 \cdot 6^{* * *}$ & $3 \cdot 2 \pm 0 \cdot 6^{*}$ \\
AmB+Ibogaine $\|$ & $3 \cdot 9 \pm 0 \cdot 7^{* * *}$ & $2 \cdot 3 \pm 0 \cdot 7^{*, * *}$ \\
\hline
\end{tabular}

$\dagger \mathrm{BALB} / \mathrm{c}$ mice inoculated intragastrically with $1 \times 10^{8}$ viable C. albicans cells after being fed with amoxicillin and amikacin for 7 days.

\$Mice treated intraperitoneally with $0.5 \mathrm{mg} \mathrm{AmB} \mathrm{kg}^{-1}$ from day 0 to day 5 of infection.

\$Mice treated intraperitoneally with $5 \mathrm{mg}$ ibogaine $\mathrm{kg}^{-1}$ from day 0 to day 5 of infection.

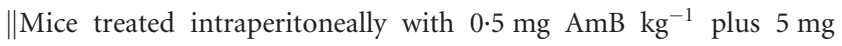
ibogaine $\mathrm{kg}^{-1}$ from day 0 to day 5 of infection.

medium containing glucose. Different lipase or phospholipase genes are expressed under various environmental conditions. For example, LIP1, a gene that encodes a lipase, is expressed when C. albicans is grown in media containing Tweens or triglycerides, while in the presence of carbohydrates the gene expression is inhibited (Fu et al., 1997). Conversely, a PLB gene encoding phospholipase B is most highly expressed in a medium with a high glucose concentration. Ibogaine inhibited the lipolytic activity of the yeast grown in both YPG and YNB/Tween 40 media. The substance also tended to suppress the lipase or phospholipase secretion as detected on egg yolk agar. At the same time, it should be taken into account that egg yolk contains substrates for both phospholipases and lipases (Fu et al., 1997). In addition, C. albicans was shown to secrete an extracellular esterase in a medium containing Tween 80 as the sole carbon source (Tsuboi et al., 1996).

Ibogaine is a naturally occurring compound with antiaddictive properties (Mash et al., 2000). A few investigations in vivo have demonstrated that ibogaine is rapidly transformed to 12-hydroxyibogaine (noribogaine), which persists in the bloodstream for at least 1 day (Baumann et al., 2001a; Mash et al., 1995). Both forms cause various effects within the nervous system through binding to kappa opioid receptors and to serotonin uptake sites (Glick et al., 2000, 2001). Ibogaine at high doses can cause a degeneration of cerebellum and tremor as side effects (Baumann et al., 2001b; Molinari et al., 1996). In clinical studies ibogaine has been administered in drug-dependent persons in single or triple 
doses (400-800 mg), which is equivalent to a mean dose above $80 \mathrm{mg} \mathrm{kg}^{-1}$ (Glick et al., 2001). At a dose of $40 \mathrm{mg} \mathrm{kg}^{-1}$ this compound has been investigated in rat models (Hough et al., 2000). We have applied ibogaine at a low dose of $5 \mathrm{mg} \mathrm{kg}^{-1}$ in order to avoid possible adverse effects.

We showed here that ibogaine is capable of diminishing the mortality in mice of systemic $C$. albicans infections by reducing the organ colonization. At the late stage of infection (28 days) in the control and in ibogaine-treated groups, the kidney colonization tended to decrease. The lack of a direct anticandidacidal effect could have been because in the early phase ibogaine prevented colonization through candidastatic mechanisms, which were not sufficient for the eradication of the pathogen. Also, the action of the compound might differ in various tissues. Data from the literature show that after intraperitoneal administration of ibogaine in rats $\left(40 \mathrm{mg} \mathrm{kg}^{-1}\right)$ it is accumulated mainly in adipose tissue and is detected to a lesser extent in the brain, liver and kidneys (Hough et al., 1996). Usually in experimental models of gastrointestinal C. albicans infection, a translocation of the yeast to internal organs is achieved by treatment with immunosuppressive agents. In the present experiments, such dissemination was induced by the use of a high inoculation dose in addition to a prolonged antibiotic application. The results show that ibogaine administered in the first 5 days of infection effectively decreased stomach colonization and prevented the yeast migration into the kidneys.

In vitro data have demonstrated that ibogaine suppresses T-cell, B-cell and natural-killer-cell functions in a dosedependent manner but has no effect on macrophages (House et al., 1995). We tried to determine whether its administration in systemic infections might influence the specific antiCandida responses. Immunocompetent individuals express positive DTH reactions to C. albicans in correlation with a decreased progression of systemic infection (Fidel, 2004). IFN $-\gamma$ is one of the major cytokines playing a decisive role for the early protective response to the fungus and underlying the development of DTH response (O'Garra et al., 1997). Data suggest that under the scheme used, ibogaine does not affect the late immune responses, at least in systemic infections. The DTH response to $C$. albicans was not significantly influenced in ibogaine-treated mice, neither was IFN- $\gamma$ production changed. These results do not exclude the fact that other cellular or humoral anti-infectious mechanisms might be affected.

AmB is the most frequently used antibiotic for severe invasive fungal infections, despite its renal toxicity. It is desirable to use $\mathrm{AmB}$ at lower doses but without the risk that the pathogen might invade further into the organs. This goal might be achieved by a combination of agents with different mechanisms of action. In the present study we administered $\mathrm{AmB}$ at a suboptimal dose together with ibogaine. The results show that the combination decreased the stomach and kidney colonization by C. albicans more effectively than each substance alone. A combination of classical antibiotics and lipase inhibitors appears to be promising because candida- cidal activity can be supported by suppression of fungus penetration into the host cells. Further investigations are needed to confirm the correlation between the antilipase activity of ibogaine and its beneficial effect in C. albicans infection.

\section{ACKNOWLEDGEMENTS}

This work was partially supported by a CNR-NATO advanced fellowship (call no. 215.35 S of 30-4-2003) to Martin Yordanov, by a Bilateral Scientific Cooperation Agreement between the University 'La Sapienza' and the Bulgarian Academy of Sciences, and by the Bulgarian National Fund for Scientific Research (grant L-1208).

\section{REFERENCES}

Andriole, V. T. (1999). The 1998 Garrod lecture. Current and future antifungal therapy: new targets for antifungal agents. J Antimicrob Chemother 44, 151-162.

Baumann, M. H., Rothman, R. B., Pablo, J. P. \& Mash, D. C. (2001a). In vivo neurobiological effects of ibogaine and its O-desmethyl metabolite, 12-hydroxyibogamine (noribogaine), in rats. J Pharmacol Exp Ther 297, 531-539.

Baumann, M. H., Pablo, J., Ali, S. F., Rothman, R. B. \& Mash, D. C. (2001b). Comparative neuropharmacology of ibogaine and its Odesmethyl metabolite, noribogaine. Alkaloids Chem Biol 56, 79-113.

Bennett, D. E., McCreary, C. E. \& Coleman, D. C. (1998). Genetic characterization of a phospholipase $\mathrm{C}$ gene from Candida albicans: presence of homologous sequences in Candida species other than Candida albicans. Microbiology 144, 55-72.

Cox, G. M., McDade, H. C., Chen, S. C. \& 8 other authors (2001). Extracellular phospholipase activity is a virulence factor for Cryptococcus neoformans. Mol Microbiol 39, 166-175.

Fidel, P. L., Jr (2004). History and new insights into host defense against vaginal candidiasis. Trends Microbiol 12, 220-227.

Fidel, P. L. Jr, Vazquez, J. A. \& Sobel, J. D. (1999). Candida glabrata: review of epidemiology, pathogenesis, and clinical disease with comparison to C. albicans. Clin Microbiol Rev 12, 80-96.

Fu, Y., Ibrahim, A. S., Fonzi, W., Zhou, X., Ramos, C. F. \& Ghannoum, M. A. (1997). Cloning and characterization of a gene (LIP1) which encodes a lipase from the pathogenic yeast Candida albicans. Microbiology 143, 331-340.

Ghannoum, M. A. (2000). Potential role of phospholipases in virulence and fungal pathogenesis. Clin Microbiol Rev 13, 122-143.

Glick, S. D., Maisonneuve, I. M. \& Szumlinski, K. K. (2000). 18-Methoxycoronaridine (18-MC) and ibogaine: comparison of antiaddictive efficacy, toxicity, and mechanisms of action. Ann N Y Acad Sci 914, 369-386.

Glick, S. D., Maisonneuve, I. M. \& Szumlinski, K. K. (2001). Mechanisms of action of ibogaine: relevance to putative therapeutic effects and development of a safer iboga alkaloid congener. Alkaloids Chem Biol 56, 39-53.

Hanel, H., Kirsch, R., Schmidts, H. L. \& Kottmann, H. (1995). New systematically active antimycotics from the beta-blocker category. Mycoses 38, 251-264.

Hough, L. B., Pearl, S. M. \& Glick, S. D. (1996). Tissue distribution of ibogaine after intraperitoneal and subcutaneous administration. Life Sci 58, PL119-PL122.

Hough, L. B., Bagal, A. A. \& Glick, S. D. (2000). Pharmacokinetic characterization of the indole alkaloid ibogaine in rats. Methods Find Exp Clin Pharmacol 22, 77-81. 
House, R. V., Thomas, P. T. \& Bhargava, H. N. (1995). Comparison of the hallucinogenic indole alkaloids ibogaine and harmaline for potential immunomodulatory activity. Pharmacology 51, 56-65.

Hube, B., Stehr, F., Bossenz, M., Mazur, A., Kretschmar, M. \& Schafer, W. (2000). Secreted lipases of Candida albicans: cloning, characterisation and expression analysis of a new gene family with at least ten members. Arch Microbiol 174, 362-374.

Hube, B., Hess, D., Baker, C. A., Schaller, M., Schafer, W. \& Dolan, J. W. (2001). The role and relevance of phospholipase D1 during growth and dimorphism of Candida albicans. Microbiology 147, 879-889.

Kariba, R. M., Houghton, P. J. \& Yenesew, A. (2002). Antimicrobial activities of a new schizozygane indoline alkaloid from Schizozygia coffaeoides and the revised structure of isoschizogaline. J Nat Prod 65, 566-569.

Komshian, S. V., Uwaydah, A. K., Sobel, J. D. \& Crane, L. R. (1989). Fungemia caused by Candida species and Torulopsis glabrata in the hospitalized patient: frequency, characteristics, and evaluation of factors influencing outcome. Rev Infect Dis 11, 379-390.

Leidich, S. D., Ibrahim, A. S., Fu, Y. \& 8 other authors (1998). Cloning and disruption of caPLB1, a phospholipase B gene involved in the pathogenicity of Candida albicans. J Biol Chem 273, 26078-26086.

Mash, D. C., Staley, J. K., Pablo, J. P., Holohean, A. M., Hackman, J. C. \& Davidoff, R. A. (1995). Properties of ibogaine and its principal metabolite (12-hydroxyibogamine) at the MK- 801 binding site of the NMDA receptor complex. Neurosci Lett 192, 53-56.

Mash, D. C., Kovera, C. A., Pablo, J., Tyndale, R. F., Ervin, F. D., Williams, I. C., Singleton, E. G. \& Mayor, M. (2000). Ibogaine: complex pharmacokinetics, concerns for safety, and preliminary efficacy measures. Ann N Y Acad Sci 914, 394-401.

Molinari, H. H., Maisonneuve, I. M. \& Glick, S. D. (1996). Ibogaine neurotoxicity: a re-evaluation. Brain Res 737, 255-262.

Mukherjee, P. K., Seshan, K. R., Leidich, S. D., Chandra, J., Cole, G. T. \&
Ghannoum, M. A. (2001). Reintroduction of the PLB1 gene into Candida albicans restores virulence in vivo. Microbiology 147, 25852597.

O'Garra, A., Steinman, L. \& Gijbels, K. (1997). CD4+ T-cell subsets in autoimmunity. Curr Opin Immunol 9, 872-883.

Pfaller, M. A. (1996). Nosocomial candidiasis: emerging species, reservoirs, and modes of transmission. Clin Infect Dis 22, S89-S94.

Portnoy, D. A., Smith, G. A. \& Goldfine, H. (1994). Phospholipases C and the pathogenesis of Listeria. Braz J Med Biol Res 27, 357-361.

Price, M. F., Wilkinson, I. D. \& Gentry, L. O. (1982). Plate method for detection of phospholipase activity in Candida albicans. Sabouraudia 20, 7-14.

Saffer, L. D. \& Schwartzman, J. D. (1991). A soluble phospholipase of Toxoplasma gondii associated with host cell penetration. J Protozool 38, $454-460$.

Shearer, G. M. (1998). HIV-induced immunopathogenesis. Immunity 9, 587-593.

Songer, J. G. (1997). Bacterial phospholipases and their role in virulence. Trends Microbiol 5, 156-161.

Sugiyama, Y., Nakashima, S., Mirbod, F., Kanoh, H., Kitajima, Y., Ghannoum, M. A. \& Nozawa, Y. (1999). Molecular cloning of a second phospholipase B gene, caPLB2 from Candida albicans. Med Mycol 37, 61-67.

Titball, R. W. (1993). Bacterial phospholipases C. Microbiol Rev 57, 347-366.

Tsuboi, R., Komatsuzaki, H. \& Ogawa, H. (1996). Induction of an extracellular esterase from Candida albicans and some of its properties. Infect Immun 64, 2936-2940.

Wenzel, R. P. (1995). Nosocomial candidemia: risk factors and attributable mortality. Clin Infect Dis 20, 1531-1534. 